\title{
ОРГАНІЗАЦІЙНО-ЕКОНОМІЧНИЙ АСПЕКТ ВИКОРИСТАННЯ ДОСВІДУ СТВОРЕННЯ ТА ДІЯЛЬНОСТІ АНТИКОРУПЦІЙНИХ СТРУКТУР КРАЇН ЄС В РОБОТІ ЩОДО ЗАПОБІГАННЯ ТА ПРОТИДІЇ КОРУПЦЇ̈ В УКРАЇНІ
}

\author{
Чередниченко О.Ю., к.е.н., доцент, докторант (УкрДУЗТ)
}

У статті розглянуто європейський досвід створення органів щзодо запобігання ŭ протидії корупчії з метою вироблення основних напрямів удосконалення правового механізму діяльності антикорупційних структур в України. На основі аналізу основних нормативно-правових актів міжнародного й національного права, досвіду європейських держав аргументовано висловлені положення щзодо пріоритетних шляхів вдосконалення чинного законодавства у сфері запобігання й протидї корупиії в нашій державі. Зроблено висновок, щуо європейський досвід протидії корупиії $і$ застосування антикорупційного законодавства має на меті використання всього арсеналу правових засобів боротьби і застосування превентивних інструментів як пріоритетних.

Ключові слова: корупція, корупційні прояви, міжннародний досвід, Свропейський Союз, моніторинг, правоохоронні органи, фінансовий контроль, громадський контроль.

\section{ОРГАНИЗАЦИОННО-ЭКОНОМИЧЕСКИЙ АСПЕКТ ИСПОЛЬЗОВАНИЯ ОПЫТА СОЗДАНИЯ И ДЕЯТЕЛЬНОСТИ АНТИКОРРУПЦИОННЫХ СТРУКТУР СТРАН ЕС В РАБОТЕ ПО ПРЕДОТВРАЩЕНИЯ И ПРОТИВОДЕЙСТВИЯ КОРРУПЦИИ В УКРАИНЕ}

\author{
Чередниченко А.Ю., к.е.н., доцент, докторант (УкрГУЖТ)
}

В статье рассмотрен европейский опыт создания органов по предотвращению u противодействию коррупции с целью выработки основных направлений совершенствования правового механизма деятельности антикоррупчионных структур в Украине. На основе анализа основных нормативно-правовых актов международного и национального права, опыта европейских государств аргументировано высказанные положения относительно приоритетных путей совершенствования действующего законодательства в сфере предотвращения и противодействия коррупџии в нашем государстве. Сделан вывод о том, что европейский опыт противодействия коррупции и применения антикоррупчионного законодательства нацелен на использование всего арсенала средств борьбы и использования, в первую очередь, превентивных инструментов качестве приоритетных.

Ключевые слова: коррупция, коррупционные проявления, международный опыт, Европейский Союз, мониторинг, правоохранительные органы, финансовый контроль, общественный контроль. 


\section{ORGANIZATIONAL-ECONOMIC ASPECTS OF THE USE OF EXPERIENCE OF CREATION AND ACTIVITY OF ANTI- CORRUPTION AGENCIES OF THE EU IN THE WORK OF PREVENTION AND COUNTERACTION OF CORRUPTION IN UKRAINE}

\section{Cherednychenko O.U., Candidate of Economic Sciences, associate professor (USURT)}

The article considers the European experience of creation department to prevent and combat corruption with the aim of developing the basic directions of improvement of the activities of anti-corruption agencies in Ukraine. Based on the analysis of the main legal acts of international and national law, the experience of the European States argued made provisions for the priority ways of improving current legislation in the sphere of prevention and counteraction of corruption in our country. It is concluded that the European experience of anti-corruption and anti-corruption legislation aimed to use the whole arsenal of means of struggle. Special attention in European countries on the use of preventive tools, they are treated as the priority that it is important to use in organizing activities to combat corruption in Ukraine.

Keywords: corruption, international experience, the European Union, monitoring, law enforcement, financial control, public control.

Постановка проблеми та ї̈ зв'язки
3 науковими чи практичними
завданнями.
Незважаючи

багатоаспектність природи виникнення та поширення корупційних проявів у кожній окремій державі, до основних факторів, що сприяють їх поширенню, можна віднести, 3 одного боку, зростаюче зубожіння широких верств населення, погіршення криміногенної ситуації, високі показники нерівності розподілу прибутків, відсутність системи соціального захисту в одних країнах, а 3 іншого - нарощування економічного потенціалу та щорічне збільшення фінансових надходжень у вигляді іноземних інвестицій - в інших країнах. Аналіз міжнародного досвіду боротьби з корупцією свідчить про те, що за сучасних умов прояви корупції стали тими чинниками, що створюють реальну загрозу національній безпеці та демократичному розвитку більшості країн світу, негативно впливають на всі сторони суспільного життя.

Корупція у більшості держав Центральної та Східної Європи, а також у країнах, які виникли на пострадянському просторі, тісно пов'язана 3 тим, що вони знаходяться в стані економічної та суспільної трансформації. Корупція, як соціальне явище, притаманна будь-якому суспільству та будь-якій державі. Жодна країна у світі сьогодні не може оголосити себе вільною від корупції. Однак окремим країнам світу вдається ефективно боротися 3 цим негативним явищем.

Аналіз останніх досліджень $\boldsymbol{i}$ публікацій. На сучасному етапі розвитку нашої держави особливого значення набувають наукові дослідження питань протидії й запобігання корупції. Теоретичні питання термінологічної визначеності понять в сфері протидії корупції розглядають у своїх дослідженнях $Г$. Атаманчук, С. Серьогін, С. Молдабаєв [13]. I. Вітик [4] вивчає окреслену проблему через призму реформування правоохоронних органів. Окремі аспекти світового досвіду протидії тіньовій економіці та вирішення багатогранних теоретико-методичних проблем щодо корупційних проявів представлено у 
наукових працях Мунтіяна В., Сосніна О., Чемериса I., Чубатої Л., Чубенко I., Уточкіної Ю., Яцківа І. [5-11] та інших дослідників.

Виділення невирімених частин загальної проблеми. Враховуючи значні досягнення вищезазначених вчених $\mathrm{y}$ вирішенні проблем протидії корупції, потребує подальшого системного вивчення питання імплементації європейського досвіду створення та діяльності антикорупційних структур 3 метою розроблення цільових програм щодо протидії масштабній корупції.

Метою cmami $\epsilon$ обгрунтування теоретико-методичних засад та прикладних рекомендацій щодо використання у вітчизняній практиці запобігання та протидіï корупції європейського позитивного досвіду створення та діяльності антикорупційних структур протидії тінізації економіки України.

Виклад основного матеріалу. Чинники успішної протидії корупції вже давно відомі та апробовані міжнародною спільнотою. Це, насамперед, відкритість влади, прозорість та зрозумілість процедур прийняття державних рішень, дієві механізми контролю за діяльністю державних органів 3 боку громадянського суспільства, свобода слова, свобода та незалежність засобів масової інформації.

Однією 3 головних складових формування і реалізації ефективної системи боротьби 3 корупцією $\epsilon$ не тільки чітка взаємодія державних, у першу чергу правоохоронних органів, на регіональному i міжнародному рівнях, a i ïх участь $y$ заходах боротьби 3 цим негативним явищем, запроваджених у межах Організації Об’єднаних Націй, Радою Європи, Інтерполом, Міжнародним валютним фондом, Світовим банком та іншими міжнародними інституціями.

Так, найважливішими серед останніх документів Європейського Союзу у сфері боротьби з корупцією $є$ Комюніке Європейської комісії від 28 травня 2003 р. щодо комплексної політики Європейського
Союзу з протидії корупції, в якій визначено основні засади боротьби з цим негативним явищем в Євросоюзі та окреслено принципи вдосконалення протидії корупції в нових країнах-членах, країнах-кандидатах і третіх країнах, а також Рамкове рішення Ради Європейського Союзу № 568 від 22 липня 2003 р. «Про боротьбу з корупцією в приватному секторі», в якому визначається поняття «активної» та «пасивної» корупції $\mathrm{i}$ встановлюються санкції у відношенні осіб, у тому числі юридичних, за вчинення такого роду злочинів. Основною метою створеної у травні 1999 року «Групи країн проти корупції» (GRECO), що діє в межах Ради Європи, є оцінка рівня корупції в державах-членах організації, виявлення недоліків у національних механізмах боротьби 3 корупцією, підтримка в проведенні необхідних законодавчих та інституційних реформ у цій сфері, здійснення контролю за виконанням угод i правових документів, прийнятих Радою Свропи відповідно до програми дій проти корупції.

Досить чітка й ефективна система боротьби 3 корупцією, яка спирається на солідну нормативно-правову базу та однозначну підтримку суспільства діє у Фінляндії. Саме цю країну міжнародна неурядова організація по боротьбі 3 корупцією «Трансперенсі Інтернешнл» визначає як одну з найменш корумпованих країн серед 133 країн світу. Фінляндія як член Свропейського Союзу $є$ учасником усіх основних нормативних документів Євросоюзу 3 питань боротьби 3 організованою злочинністю та корупцією. В той же час, імплементація європейських законів у національну правову систему здійснюється цією країною досить виважено. Головним принципом цього процесу $\epsilon$ органічне поєднання національного законодавства Фінляндії із загальноєвропейським із мінімально можливими змінами першого. Для фінської правової системи не є характерними закони 3 використанням терміну «боротьба» 3 визначенням певного виду злочину. 
Фінський законодавець заклав принципи попередження та застереження вчинення злочинів у кожному нормативно-правовому акті, що визначають конкретну сферу діяльності, а не вид злочину. Згідно 3 положеннями Кримінального кодексу Фінляндії, за вчинення дій, що можуть кваліфікуватися як «корупція», передбачено санкції від штрафу до ув'язнення строком до чотирьох років в залежності від ступеня суспільної небезпеки злочину.

У галузі боротьби 3 корупцією у Бельгії пішли не лише традиційним, так званим репресивним шляхом установлення кримінальної відповідальності за корупційні діяння, а також подбали про попередження корупції. Так ця проблема знайшла своє відображення у межах реформи COPERNIC (модернізації державного управління), зокрема у реформі сектору фінансового контролю. Бельгія розширила поняття корупції стосовно зловживання владою, не обмежуючись лише кримінальним аспектом, а й залишивши місце для таких понять, як роз'яснення норм (правил, стандартів), їх нагадування, транспарентність поведінки, що приведе до вироблення кодексу поведінки (деонтології).

Досвід боротьби 3 корупцією у Німеччині та Словаччині свідчить про ефективність задіяння громадськості для боротьби 3 корупцією. Зокрема, відомство кримінальної поліції федеральної землі Нижня Саксонія впровадило прийом анонімних повідомлень від громадян про економічні злочини. У Федеративній Республіці Німеччина в основу боротьби 3 корупцією покладено завдання знищення матеріальної, насамперед фінансової бази злочинних угруповань. Це досягається шляхом конфіскації майна i створення належної правової бази для унеможливлення «відмивання» «брудних» грошей.

Основне завдання німецького уряду у сфері запобігання корупції полягає в тому, щоб у результаті законодавчих, організаційних, кадрових та інших заходів унеможливити зловживання державного службовця своїм посадовим становищем [8].

У структурі Міністерства внутрішніх справ Словацької Республіки діє Антикорупційний комітет, до повноважень якого входить проведення превентивних заходів та розслідування фактів корупції серед співробітників міністерства та поліцейських структур країни. У Словацькій Республіці ліквідовано Центральне координаційне управління боротьби 3 корупцією та Комітет боротьби 3 корупцією і створено відділ боротьби з корупцією Секретаріату Уряду Словаччини, основним завданням якого $€$ координація дій міністерств та відомств у сфері боротьби 3 корупцією. Безпосередньо реалізацією заходів у межах «Національної програми боротьби 3 корупцією» займаються Управління боротьби 3 корупцією Президії поліцейського корпусу МВС Словаччини та Словацька інформаційна служба (CIC). Крім цього, основні повноваження по боротьбі 3 корупцією перейшли від Міністерства фінансів до Міністерства юстиції Словаччини.

3 метою отримання інформації про посадові злочини та локалізації цього явища в правоохоронних структурах установлено спеціальну телефонну лінію, по якій громадяни країни можуть повідомляти про відомі їм протиправні дії правоохоронців. Одночасно в міжнародній інформаційній мережі «Інтернет» створено веб-сторінку, де бажаючі можуть висловити свої пропозиції щодо необхідних заходів по боротьбі 3 корупцією в державних установах.

Крім того, в деяких державах у боротьбі 3 корупцією активно використовуються різноманітні громадські організації. Зокрема у Швеції незалежним моніторингом за рівнем корумпованості в тих чи інших сферах суспільства займається створена 1994 року громадська 
організація «Демократичний аудит», яка об'єднує в собі провідних шведських політологів, економістів та інших науковців. Поряд із моніторингом стану розвитку демократичних свобод у шведському суспільстві, ця організація займається i вивченням специфічних питань, у т. ч. пов'язаних із боротьбою 3 корупцією.

Разом 3 цим слід зазначити, що втілення в життя ефективних заходів із боротьби 3 корупційними проявами в окремих країнах не проходить без суттєвих проблем, подолання яких вимагає підвищення ефективності ведення боротьби 3 корупцією, створення дієздатних систем протидії цьому негативному явищу.

Так не дивлячись на актуальність вказаного питання у Польщі, у цій країні досить довго не приймався окремий законодавчий акт щодо корупції. Вважалося, що достатньою правовою основою для боротьби з корупцією є низка статей Кримінального кодексу, які передбачають відповідальність за різні види хабарництва та перевищення повноважень посадовими особами. Однак загрозлива для держави поширеність корупції та потреба більш повної реалізації підписаних Польщею (у зв'язку зі вступом до Свропейського Союзу) міжнародноправових угод спонукала польську владу до вжиття додаткових заходів. Зокрема, наприкінці 2002 року урядом Польщі затверджено Державну програму боротьби 3 корупцією під назвою «Антикорупційна стратегія». На виконання цієї програми створена та працює Надзвичайна кодифікаційна комісія сейму Польщі, яка займається змінами до Кримінального, Кримінально-процесуального та Кримінально-виконавчого кодексів

Крім того, 324 серпня 2006 р. введено в дію Закон про «Центральне антикорупційне Управління (ЦАУ, Centralny Urzad Antykorupcyjny)». Основною метою діяльності ЦАУ $\epsilon$ боротьба зі зловживаннями владою та використанням привілеїв для досягнення особистої і майнової користі, а також діяльністю, спрямованою проти економічних інтересів держави. ЦАУ повинне переслідувати корупційну злочинність, ретельно перевіряти майнові декларації чиновників та працівників сфери самоуправління, слідкувати за спробами порушити заборону поєднання громадських (державних) функцій із господарською діяльністю. Для боротьби 3 проявами корупції в лавах суддівського корпусу, інших учасників судового процесу, зали проведення засідань у польських судах 3 2006 року почали обладнуватись відеокамерами та мікрофонами, які дозволять фіксувати хід судових засідань та поведінку кожного 3 їх учасників (суддів, прокурорів, адвокатів, протоколістів). Практика боротьби правоохоронних органів Польщі 3 проявами корупції свідчить також про ефективність застосування Закону про протидію введенню до фінансового обігу матеріальних засобів нелегального чи невизначеного походження, а також про протидію фінансуванню тероризму від 16 листопада 2000p. Досить значний ефект у справі протидії корупційним явищам досягнуто при застосуванні Закону Республіки Польща від 16 листопада 2000 p., яким створено новий державний орган фінансової розвідки, що передбачає втілення таких завдань: припинення злочинних дій у фінансовому секторі та створення банку даних для всіх компетентних державних інститутів, які протидіють використанню нелегальних джерел доходів. Генеральний інспектор фінансової інформації виконує посередницькі функції по збору, аналізу, оцінці та передачі даних, а також координації взаємодії між різними фінансовими інститутами i правоохоронними органами.

Досить активно намагаються боротися 3 корупцією уряди країн Балтії. Одночасно, на думку спеціалістів, унаслідок нескоординованості дій між правоохоронними органами Латвії 
(боротьбу з цим негативним явищем у країні здійснюють аж 16 різних структур, у т. ч. правоохоронних), країна залишається найкорумпованішою у Свропейському Союзі. У зв'язку зі вступом Литви до Європейського Союзу у заяві Європейського Парламенту теж зазначається про необхідність активізації боротьби в цій країні 3 корупцією та організованою злочинністю, особливо на кордоні.

3 огляду на актуальність проблеми боротьби з корупцією, одним із головних завдань сучасності для багатьох держав світу $є$ перегляд комплексу організаційноправових та інших заходів на національному рівні 3 метою їх удосконалення, підвищення рівня взаємодії на двосторонньому та регіональному рівнях, а також активізація діяльності в межах міжнародних організацій у сфері боротьби 3 корупцією та організованою злочинністю.

Практика роботи у цьому напрямі правоохоронних органів зарубіжних країн свідчить про те, що саме досконалість нормативно-правового забезпечення протидії вказаному явищу та наявність ефективної системи протидії йому на національному й міжнародному рівнях $\epsilon$ однією 3 головних умов успішного вирішення зазначеного питання. Слід також зазначити, що у багатьох державах світу 3 метою здійснення цілеспрямованих заходів розроблені, ухвалені та діють спеціальні закони щодо боротьби з корупцією.

Наприклад, у Румунії з 2000 року діє закон № 78/2000 «Про попередження, виявлення та покарання корупційних дій», а з 1 березня 2003 р. набув чинності закон № 39 від 21 січня 2003 р. «Про попередження та боротьбу з організованою злочинністю».

У деяких країнах світу існують закони, які безпосередньо спрямовані на боротьбу з корупцією, або регулюють окремі аспекти у межах законів щодо боротьби з організованою злочинністю або законах, які регулюють державну службу (Білорусь, Литва, Румунія).
Так, у ст. 2 Закону Республіки Білорусь № 47-3 від 10 червня 1997 р. «Про заходи боротьби 3 організованою злочинністю та корупцією» вказується, що «види та ознаки діянь, пов'язаних 3 організованою злочинністю та корупцією, а також кримінально-правові заходи покарання осіб, що їх скоїли, встановлюються Кримінальним кодексом Республіки Білорусь».

Водночас, у багатьох державах світу, зокрема в Австрії, Чехії, Швеції та в деяких інших, немає єдиного спеціального закону у сфері боротьби з корупцією. У цих країнах нормативно-правові документи 3 вказаних питань охоплюють низку законодавчих актів, а діяльність державних органів регламентована відповідними частинами Кримінального кодексу або, як один із варіантів, на основі співробітництва 3 міжнародними організаціями, насамперед Інтерполом і Європолом.

Наприклад, у Швеції проблема корупції не розглядається як така, що становить значну небезпеку для суспільства, відповідно, у країні не існує будь-яких спеціальних урядових програм чи спеціалізованих державних органів по боротьбі з корупцією. Питання корупції та хабарництва виписані у загальному шведському законодавстві, зокрема Кримінальному кодексі, Кодексі про судочинство, Акти про аудит та інших законодавчих і підзаконних актах.

Національне законодавство Великобританії у сфері боротьби 3 корупцією є досить розгалуженим, оскільки певні норми матеріального права, які стосуються правовідносин, що виникають унаслідок вчинення тими чи іншими посадовими особами корупційних дій, можуть міститися у різних актах (не тільки кримінального, а також інших галузях права). 3 огляду на те, що законодавство у цій сфері не є кодифікованим, існувала певна складність його застосування правоохоронними органами Великобританії, тому 24 березня 2005p. МВC Великобританії внесло на розгляд 
заінтересованих міністерств і відомств Великобританії законопроект про боротьбу 3 корупцією. Оновлений законопроект узагальнює попередне антикорупційне законодавство, i серед іншого скасовує парламентський імунітет від відповідальності за діяння, що містять ознаки корупційних.

Удосконалення законодавчої бази 3 метою ефективної боротьби 3 корупцією та організованою злочинністю в багатьох державах світу стало поштовхом для розробки комплексу інших додаткових заходів організаційного, правового та інформаційного характеру. Зокрема, у деяких державах ухвалено національні стратегії (доктрини, директиви тощо) або програми у сфері боротьби з корупцією, які мають перспективний характер i передбачають здійснення комплексу організаційно-правових та інших заходів щодо подальшого вдосконалення існуючої системи протидії корупції.

Так, парламент Швейцарської Конфедерації, виходячи 3 необхідності адекватного реагування на потенціальні загрози внутрішній безпеці, 3 вересня 1999 p. затвердив «Директиви щодо організації та здійснення політики безпеки», що стало першою фазою створення і розвитку нових інструментів у сфері боротьби з корупцією та організованою злочинністю у країні. 3 метою удосконалення системи забезпечення національної безпеки 2002 року у Швейцарії було фактично завершено формування нової структури державних органів у цій сфері.

Важливу роль у боротьбі 3 корупцією відіграють Національні програми по боротьбі 3 корупцією, прийняті урядами багатьох держав світу. Першочергову увагу в цих програмах приділено створенню механізмів та системи ефективного контролю, в т. ч. і за роботою недержавних організацій та широкого спектру незалежних засобів масової інформації. 3 метою проведення ефективної політики у сфері боротьби 3 корупцією у більшості держав створені та діють спеціалізовані антикорупційні структури.

Так, типовою для багатьох країн Західної Європи $\epsilon$ структура спеціалізованих служб у Франції: Центральна рахункова Палата (лише виявляє порушення), Служба попередження корупції, Центральна дирекція юридичної поліції, Центральна дирекція загального інформування, Центральний офіс покарання фінансових порушень у фінансовій сфері. Усі ці структури $\epsilon$ державними i фінансуються 3 бюджету, кожна служба працює у визначеній для неї сфері. Одночасно французькі фахівці вважають, що створення спеціалізованих служб і органів по боротьбі з корупцією має розглядатися не як головна мета, а як засіб для досягнення мети.

Урядом Румунії у березні 2003 року створена спеціалізована структура по боротьбі 3 корупцією - Національна Прокуратура по Антикорупції. (Зазначена прокуратура розслідує справи, в яких спричинена матеріальна шкода дорівнює еквіваленту 100 тис. євро або протиправні дії, які скоєні членами парламенту, уряду, судових органів, префектами, керівниками державних організацій, банків тощо).

$$
\text { В Італії для боротьби } 3
$$

організованою злочинністю, в тому числі й корупцією, створено міжвідомчий спеціальний орган - «Управління розслідувань Антимафія» (ДІА). Основна частина кадрів ДІА складають фахівці слідчих органів Державної поліції, карабінерів та Фінансової гвардії із залученням цивільних фахівців у галузі інформатики, технічного та адміністративного забезпечення. До компетенції цього органу віднесено злочини 3 наявністю ознак «угруповання мафіозного типу». Як позитивний приклад $\epsilon$ втілення в політико-правове поле Італії принципів розподілу влад, незалежності судової влади від урядового впливу та втручання інших гілок влади. Завдяки цьому Італійська судова система $\epsilon$ найважливішою із трьох гілок влади в системі механізмів боротьби з корупцією. В 
Конституції Італії втілено політичне рішення про надання Верховній Раді суддів виключних прав на заохочення та покарання суддів. Дві третини членів Ради обираються суддями, і одна третина політичними партіями [7]. Крім того, адміністративні комісії мають статус судів, а Конституція передбачає адміністративне провадження $з$ деяких кримінальних справ. Дієвим антикорупційним механізмом слід визнати також те, що судді, прокурори i слідчі вважаються членами однієї професії і регулярно міняються ролями. Кожна прокуратура $\epsilon$ автономною. Кожний прокурор має такі ж гарантії незалежності, як і судді.

У деяких інших державах повноваження щодо протидії корупції покладено на одну із силових структур або їх розподілено між кількома відомствами.

3 метою координації діяльності державних органів у сфері боротьби 3 корупцією на національному рівні та підготовки пропозицій щодо вдосконалення існуючої системи протидії цьому явищу в багатьох державах створено міжвідомчі комісії 3 представників профільних міністерств і відомств.

Зокрема в Угорській Республіці було створено комісію з фахівців у галузях права, управління та економіки, якою на сьогодні розроблені проекти та внесені зміни $\mathrm{i}$ доповнення до понад 20 законодавчих актів. Серед основних нововведень, спрямованих на протидію корупції, експерти відзначають: обмеження обігу готівкових коштів і запровадження порядку здійснення розрахунків між господарськими структурами на суми понад 200 тис. форинтів (одна тисяча доларів США) лише через банківські установи; зменшення кола осіб, які мають відстрочки та пільги у сплаті податку та митних зборів; звуження поняття податкової таємниці та підвищення рівня інформованості державно-адміністративних органів (передусім податкового управління, поліції та фінансово-митної служби).

Згідно 3 прийнятою міжнародною спільнотою Кримінальною конвенцією «Про боротьбу 3 корупцією» та ратифікованою Верховною Радою України 16 березня 2005p. Цивільною конвенцією «Про боротьбу з корупцією», розроблених Радою Європи 1999 року (м. Страсбург), а також Конвенцією ООН проти корупції (Резолюція від 31 жовтня 2003 р.), убачається за доцільне імплементувати міжнародно-правові норми вказаних документів в українське правове поле 3 метою його гармонізації 3 міжнародними правовими стандартами та впровадити світовий досвід у сфері протидії корупції, дотримуючись виваженої політики у цьому питанні.

Проведений аналіз особливостей боротьби 3 корупційними злочинами в країнах Європейського Союзу дозволяє сформувати уявлення про основи передової національної антикорупційної стратегії, розвиток якої необхідний в сьогоденні України:

- сильна політична воля вищого керівництва держави до боротьби 3 корупцією і сформована на іiї основі єдина державна політика в області боротьби 3 корупцією, яка б включала комплекс заходів державного, політичного, економічного, соціального i правового характеру. Ні законодавчі, ні адміністративні, ні будь-які інші заходи, що направлені на протидію корупції не можуть бути ефективними, якщо немає політичної волі на всіх рівнях влади;

- організований соціальний контроль 3 боку громадянського суспільства за всією системою державного адміністрування (неодмінною умовою для цього є створення атмосфери прозорості) i забезпечена можливість порушення в цих рамках кримінального переслідування правопорушників. Важливу роль тут відіграють дійсно незалежні засоби масової інформації;

- незалежність судової влади. Такий підхід всебічно ілюструє правоохоронна система Італії, Великобританії, Франції та інших країн; 
- жорстка підзвітність осіб, які наділені владними повноваженнями, перед реально незалежним органом, що здійснює моніторинг чистоти діяльності державних службовців, а також наділений повноваженнями по притягненню до відповідальності посадовців незалежно від їх місця в ієрархічній структурі влади.

Висновки. Для правових систем деяких розвинутих країн узагалі не характерно використання в законодавстві терміну «боротьба» - законодавці закладають в нормативно-правовому акті принципи попередження правопорушень, які стосуються певної сфери діяльності. За умов масштабної корупції акцент робиться саме на усуненні причин, а не на боротьбі 3 конкретними проявами.

Україна прийняла всеосяжну правову основу для боротьби з корупцією, та створила незалежні антикорупційні органи, які мають певний кредит довіри 3 боку суспільства.

Результати гармонізації мають сприяти стабілізації ситуації в цій сфері, оскільки за останні роки рівень корупції в Україні виріс i вона стала однією 3 найгостріших проблем сучасності. Це негативне явище створює реальну загрозу безпеці, демократичному розвитку держави і суспільства, констуційного ладу. Україні потрібно врахувати позитивний досвід антикорупційної діяльності європейських країн у практичній роботі 3 викоренення цих ганебних явищ.

\section{ПЕРЕЛІК ВИКОРИСТАНИХ ДЖЕРЕЛ}

1. Атаманчук Г.В. Сущность государственной службы . история, теория, закон, практика: Могорафия / Г.В. Атаманчук. - М.: РАГС, 2002. - 272 с.

2. Серьогін С. М. Мета, завдання та функції державної служби / С. М. Серьогін
// Аспекти публічного управління. - 2013. № 1. - C. 58-65.

3. Молдабаев С. Коррупция как социально-правовое явление / С. Молдабаев // ВісникНаціональної Академії прокуратури України. - 2009. - № 3. - С. 104-109.

4. Вітик I. Боротьба з корупцією в Україні крізь призму реформування правоохоронних органів: окремі нотатки до Закону Україні "Про засади запобігання та протидії корупції" / I. Вітик // Право України. - 2010. - № 11. - С. 39-43.

5. Мунтіян В. І.Економічна безпека України: монографія / В. І. Мунтіян. - К.: Вид-во НІСД при Президентові України, 1999. - $457 \mathrm{c}$.

6. Соснін О. Про необхідність використання світового досвіду в боротьбі 3 корупцією у вітчизняній практиціь // Віче. - 2014. - № 1. - С. 17.

7. Чемерис I. Зарубіжний досвід протидії корупції в системі державного управління // Стратегічні пріоритети. 2009. — № 3(12). - C. 13-16.

8. Чубата Л. В. Міжнародний досвід боротьби з проявами корупції / Л. В. Чубата // Часопис Київського університету права. - 2010. - № 2. - С. 338-342.

9. Чубенко I. Зарубіжний досвід боротьби з корупцією в органах виконавчої влади / І. Чубенко // Вісник державної служби України. - 2003. - № 1. - С. 81-87.

10. Уточкіна Ю. А. Міжнародний досвід протидії корупційним проявам / Ю. А. Уточкіна // Вісник Луганського державного університету внутрішніх справ імені Е.О. Дідоренка. - 2012. - № 5 : Спеціальний випуск: Адміністративне право та процес: реалії й перспективи розвитку. - С. 258-264.

11. Яцків I. Деякі питання застосування міжнародних механізмів протидії корупції в Україні / I. Яцків // Право України. - 2010. - № 11. - С. 259-265. 